\title{
The influence of national parliaments on the European Commission within the framework of the yellow card procedure in the context of the revision of the Posting of Workers Directive
}

\begin{abstract}
The article aims to analyse the national parliaments' capability of exerting influence on the European Commission in the framework of the yellow card procedure. The analysis is based on the actions undertaken by national parliaments of selected Member States from Western as well as Central and Eastern Europe within the period between the announcement of the European Commission proposal for a targeted revision of Directive 96/71/EC on the posting of workers and its decision to maintain the proposal. The analysis covers three variables concerning the states selected for analysis, namely the economic interest of those states, the coherence of their parliaments' respective positions and the actions undertaken by the national parliaments, including those of their members, on the international level.
\end{abstract}

Keywords: European Commission, influence, national parliaments, posting of workers, subsidiarity, yellow card, reasoned opinion

Małgorzata Wysocka - PhD student in Department of European Law, Faculty of Law and Administration, University of Warsaw; e-mail: malgorzata.wysocka@coleurope.eu; ORCID: 0000-0002$-5815-7735$. 


\section{Introduction}

The Treaty of Lisbon, called "the treaty of parliaments", strengthened the role of not only the European Parliament, but also of the national parliaments, giving them the right to participate in the decision-making process at the Union level by submitting opinions to legislative proposals in areas where the Union holds no exclusive competence. ${ }^{2}$

On 28 June 2018, a breakthrough event occurred, which will have an impact on a huge number of European enterprises, and, in consequence, on the economy of the European states. That event was the approval by the President of the European Parliament and the President of the Council of EU Directive (EU) 2018/957 of the European Parliament and of the Council of 28 June 2018 amending Directive 96/71/EC concerning the posting of workers in the framework of the provision of services. Official talks concerning revision of the Directive 96/71/EC of the European Parliament and of the Council of 16 December 1996 concerning the posting of workers in the framework of the provision of services ("the Directive") started from the presentation by the European Commission ("the Commission") of a legislative proposal ("the Proposal") on 8 March 2016. ${ }^{3}$ Both the idea of changing the rules of the posting of workers and provisions in the draft started a heated debate between the supporters and opponents of tightening the provisions. The member states of the European Union divided into two fractions, mostly along the line east - west. From the perspective of the EU law, one of the most interesting events related to the proposed revision was the procedure of a yellow card, i.e. a reasoned opinion on the lack of compliance of the draft with the principle of subsidiarity, based on Article 5(3) of the Treaty on European Union. ${ }^{4}$ The procedure was launched by 14 chambers from 11 member states. Afterwards, the Commission had the obligation to analyse the draft again, withdraw it or keep it unchanged, and then issue a document justifying the Commission's decision.

2 D. Jancic, The Game of Cards: National Parliaments in the EU and the future of the Early Warning Mechanism and the Political Dialogue, "Common Market Law Review" 2015, Vol. 52, p. 939.

3 Proposal of the European Commission of 8 March 2016 for a Directive of the European Parliament and the Council amending Directive 96/71/EC of The European Parliament and of the Council of 16 December 1996 concerning the posting of workers in the framework of the provision of services, 2016/070 (COD), Strasbourg, 8 March 2016.

4 Treaty on European Union, Official Journal of the European Union C 202 of 7 June 2016, pp. 13-45. 
This paper presents an analysis which aims to explain the following: why did the parliaments of the states of Western Europe manage to have a greater influence on the Commission's decision concerning the continuation of the work on revision of the Directive than the parliaments of Central and Eastern Europe?

The analysis is focused on the period between the announcement of the Proposal and the Commission's decision to maintain it ${ }^{5}$, that is, between 8 March and 20 July 2016, and was based on the analysis of documents adopted by the discussed chambers in the framework of subsidiarity control mechanism, the political dialogue, and also of transcripts of interparliamentary meetings and the sessions of the national parliaments and their appropriate committees, as well as of conducted interviews and statistical data from 2015.

The chambers of France (the National Assembly and the Senate) and Germany (the Bundestag and the Bundesrat) as the representatives of the most important states receiving posted workers, as well as the chambers of Poland (the Sejm and the Senate) and of the Czech Republic (the Chamber of Deputies and the Senate), as the representatives of those member states which attempted to stop the tightening of the provisions of the Directive, were selected for the purpose of the analysis. Three variables concerning the countries selected for the analysis were analysed, i.e.: economic interest, the coherence of the positions presented by the parliaments and the activity of those parliaments (including their members) on the international stage.

\section{Setting the context}

\section{The posting of workers in the framework of the provision of services}

The posting of workers is regulated by the Directive which applies to enterprises doing business in a member state, which, in the framework of providing services abroad, temporarily:

$\square$ post workers to the territory of a member states on their account and under their direction, under a contract concluded between the undertaking making the posting and the party for whom the services are intended,

$\square$ post workers to an establishment or to an undertaking owned by the group,

5 European Commission, Communication from the Commission to the European Parliament, the Council and the national parliaments on the proposal for a Directive amending the Posting of Workers Directive, with regard to the principle of subsidiarity, in accordance with Protocol No 2, $\operatorname{COM}(2016) 505$ final, Brussels, 20 July 2016. 
$\square$ being a temporary employment undertaking or placement agency, hire out a worker to a user undertaking established or operating in the territory of a member state. ${ }^{6}$

The main changes proposed by the Commission on 8 March 2016 were:

$\square$ the identity of rules applied to cross-border and local agencies supplying workers,

$\square$ the application of the employment law of the receiving state to the employment agreement of posted workers if the expected period of posting is longer than 24 months, unless the parties agreed on the applicable law,

posted workers would be subject to the same pay regulations as local workers. ${ }^{7}$

\section{Meetings concerning the posting of workers}

Within the time frame of the described research, members of the chambers involved participated in a meeting organised by the French National Assembly on 18 May 2016 ("Interparliamentary Meeting") in order to exchange views on the posting of workers, and also in two meetings of the Conference of Parliamentary Committees for Union Affairs of Parliaments of the European Union ("COSAC conference"). The COSAC conference takes place twice a year, and in the analysed period, two meetings took place - in the Hague on 13 June 2016, and in Bratislava on 11 July 2016, and it was only during the second meeting that the parliamentarians and Commissioner $\mathrm{M}$. Thyssen could exchange their views on amending the Directive.

Setting the context of the meeting, it is worth adding that every chamber of the parliament of a member state of the EU has its representative in Brussels whose role is primarily to act as an intermediary between a given chamber and other parliaments. The majority of them do not play any political role. All representatives work in the same building of the European Parliament, with the exception of German representatives who occupy a separate office outside the Parliament.

Despite the fact that the paper presents the analysis of the activity of national parliaments in a selected period, one cannot ignore the fact that the government and chambers have already attempted to influence the Commission in order to start the reform concerning the posting of workers. France was the most active

6 Article 1, Directive 96/71/EC of the European Parliament and of the Council of 16 December 1996 concerning the posting of workers in the framework of the provision of services, Official Journal of the European Communities L 18 of 21 January 1997, pp. 1-6.

7 European Commission, Communication..., op. cit., pp. 4-5. 
party in this regard, even on 28 May 2013 G. Savary ${ }^{8}$ and Ch. Guittet, the members of the French National Assembly, issued an Information Report ${ }^{9}$, in order to convince the Commission to launch the revision of the Directive. According to D. Bokhorst's thesis, "parliaments may have an influence on the writing of a proposal from the Commission"1011.

\section{The economic importance of posting}

In order to analyse the influence of national parliaments on the Commission, it is necessary that the importance of posting for individual countries, from the perspective of both the state that sends and the one that receives foreign workers in the framework of the provision of services, be understood. Despite a wide-ranging debate and emphasising by Western Europe the negative influence of posting workers from Eastern Europe on the economy of Western Europe, in reality, in 2015, that form of providing services did not exceed $0.9 \%$ of all EU workers on average. Only 2.05 million A1 certificates, i.e. documents stating the place of applicable laws regarding social insurance were issued. ${ }^{12}$

When it comes to wages, the difference in minimal wages between France and Poland in January 2015 was EUR 1,039.73, when the French minimal wage reached EUR 1,458, and the Polish minimal wage reached PLN 1,750, i.e. EUR $418.27^{13}$. The Commission measures the differences in working and wage conditions between posted workers and local ones (the differences are called "social dumping") by comparing the average wage in the sending country with the statutory minimal wage in the receiving country because a posted worker generally earns more than

8 Gilles Savary was a Member of the European Parliament in the years 1999-2009.

9 National Assembly, Rapport d'information de la commission des Affaires européennes déposé par la commission des affaires européennes sur le bilan d'activité de la commission des Affaires européennes (XIVè législature, 2012-2017), 4 April 2017, Nº 4605, p. 65.

10 D. Bokhorst, A. Schout, J.M. Wiersma, The Emperor's New Clothes? A Political Evaluation of the Early Warning Mechanism, "The International Spectator" 2015, Vol. 50, No. 2, p. 103.

11 Own translation [translator's note].

12 J. Pacolet, F. De Wispelaere, Posting of workers Report on A1 portable documents issued in 2015, HIVA - KU Leuven, December 2016, p. 21.

13 The weighted average exchange rate of EUR was PLN 4.1839 in 2015, http://www.nbp.pl/home. aspx?f=/kursy/arch_a.html; Eurofound, Statutory minimum wages in 2015: Pay-Q4 2014 (EurWORK topical update), Eurofound, 2017, pp. 1-2. 
the minimal wage. ${ }^{14}$ The difference between the Polish average wage which was PLN 3,899.78 ${ }^{15}$, i.e. EUR 932.96, in 2015, and the French minimal wage, is EUR 541.37.

Considering the above, I will examine whether the bigger economic interest of a EU member state in the posting of workers is, the more probable it is that the arguments of the parliament of that state will be considered by the Commission. By economic interest I mean financial benefits for the state's budget which are directly connected with pursuing the revision of the Directive or its withdrawal. That interest may depend on the number of received or sent workers, which, in turn, translates into whether reducing the number of received posted workers by increasing the costs of posting 16 , or retaining the current provisions which will maintain the competitiveness of companies from Central and Eastern Europe will be more beneficial for the national economy. In order to prove the validity of the question asked above, I will present data concerning the issued A1 certificates, divided by countries sending and receiving posted workers, by trends related to posting, and also by arguments used by parliamentarians in the framework of the analysed tools for influence.

\section{An overview of positions regarding the posting of workers}

The country which sends the highest number of posted workers is Poland which issued 463,174 A1 certificates ${ }^{17}$ in 2015, whereas the Czech Republic was in 17th place, with 37,174 A1 certificates issued ${ }^{18}$. Despite the significant difference in the number of posted workers, an increase in the number of postings was observed in the years 2010-2015, which may be the reason for the fact that both countries still wish to use their competitiveness. When it comes to the receiving of posted workers, the positions of both countries are similar to each other. In 2015, $0.4 \%$ of all EU posted workers arrived in the Czech Republic, whereas in the case of Poland, that rate

14 Interview \#4 with an Official, DG Employment, European Commission, Brussels, 24 April 2017.

15 Główny Urząd Statystyczny, Przeciętne miesięczne wynagrodzenie w gospodarce narodowej w latach 1950-2017, as of 23 September 2018, https://stat.gov.pl/obszary-tematyczne/rynek-pracy/ pracujacy-zatrudnieni-wynagrodzenia-koszty-pracy/przecietne-miesieczne-wynagrodzenie-wgospodarce-narodowej-w-latach-1950-2017,2,1.html.

16 The amendment to the Directive provides for changing the term "minimum rates of pay" to "remuneration", as well as the country in which social security contributions will be paid from posting longer than 24 months.

17 European Commission, Country factsheet - posted workers in Poland (2015), p. 1, as of 26 April 2017, ec.europa.eu/social/BlobServlet?docId=15203\&langId=en.

18 European Commission, Country factsheet - posted workers in the Czech Republic (2015), p. 1, as of 26 April 2017, ec.europa.eu/social/BlobServlet?docId=15187\&langId=en. 
amounted to $1.2 \%$, which differs significantly from the position of Germany and France in this respect.

France and Germany as the most important countries which receive posted workers, with $11.9 \%$ and $28 \%$ of all EU postings, respectively, are interested in restricting the influx of foreign workers. Poland is on top of the list of all countries which send the highest number of posted workers to the discussed states. It sends $16.9 \%$ of workers to France and $31.7 \%$ to Germany. ${ }^{19}$ What is essential, and what was somewhat ignored during the debate is that both of those countries also send many posted workers. In 2015, France issued 139,040 A1 certificates, whereas Germany issued 240,862 such certificates, which put that country in second place, just behind Poland. ${ }^{2021}$ Considering the posting trends, there was an increase in the number of received workers in both countries, but in the years 2010-2015, it was Germany that received a number of workers that was greater by $67.5 \%$ than in 2010, whereas France received only $10.7 \%$ more of them. ${ }^{2223}$

\section{The importance of economic arguments in the debate}

In order to influence the Commission's decision, the national parliaments could use an argument concerning the meaning of revision of the Directive for the economic situation of their states.

The first argument, frequently raised by countries opposing the revision of the Directive, was the lack of a precise justification of the proposed changes. As part of the political dialogue, the Polish Senate alleged that the draft lacked the presentation of the proposed amendment's influence on small and medium enterprises. Apart from that, in the Senate's opinion, the Commission did not provide any detailed data on the costs which would be borne by enterprises in connection with the new rules of remuneration for posted workers. ${ }^{24}$ An analogous doubt was

19 European Commission, Country factsheet - posted workers in Germany (2015), p. 2, as of 26 April 2017, http://ec.europa.eu/social/BlobServlet?docId=15188\&langId=en.

20 European Commission, Country factsheet - posted workers in France (2015), p. 1, as of 26 April 2017, http://ec.europa.eu/social/BlobServlet?docId=15194\&langId=en.

21 European Commission, Country factsheet - posted workers in Germany..., op. cit., p. 1.

22 Ibidem.

23 European Commission, Country factsheet - posted workers in France..., loc. cit.

24 Senate of the Republic of Poland, Opinion of the Foreign and European Union Affairs Committee of the Senate of the Republic of Poland on the Proposal for a Directive of the European Parliament and of the Council amending Directive 96/71/EC of the European Parliament and of the Council of 16 December 1996 concerning the posting of workers in the framework of the provision of services COM (2016) 128 adopted at the meeting of 12 April 2016, p. 1. 
raised by the Czech Senate. ${ }^{25}$ The issue which concerned changing the rules of remuneration from minimal rates to the ones applicable in the receiving country was raised both the Czech Senate and the Sejm. ${ }^{26}$ In its reasoned opinion, the Czech Chamber of Deputies presented the impact of the revision of the Directive on the state's budget, which seems to be an interesting tool for showing the Commission that changing the provisions has a great influence on the state, and even offering the minimal wage in the receiving state may increase the position of a worker posted to, say, Germany. ${ }^{27}$

The replies of the Commission to the opinions issued by the four chambers discussed above are, to a large extent, identical to one another, which was received as the weakening of the role of the national parliaments in the procedure. ${ }^{28}$ The Commission claimed that it had not aimed at equalising the level of wages in the Union, but only at the unification of norms concerning wages, applying to local and posted workers in the receiving member state. ${ }^{29}$ As far as the influence of revision of the Directive on small and medium enterprises is concerned, the Commission emphasised that amendments included in the Proposal might reduce, but not completely eliminate, competitiveness related to the costs of work of small and medium enterprises from countries in which salaries are low, due to differences which will still be present in social security contributions and in taxes. ${ }^{30}$

Despite the fact that the postulates of France and Germany were, to a great degree included in the Proposal, the representatives of these countries participated in the debate, though in a limited scope. This action is justified in literature which

25 Senate of the Czech Republic, $416^{\text {th }}$ Resolution of the Senate on the Proposal for a Directive of the European Parliament and of the Council amending Directive 96/71/EC of the European Parliament and of the Council of 16 December 1996 concerning the posting of workers in the framework of the provision of services, COM (2016) 128, 27 April 2016, p. 2.

26 Sejm of the Republic of Poland, Reasoned opinion of the Polish Sejm of 13 April 2016 stating reasons why the Sejm considers that the proposal for a directive of the European Parliament and of the Council amending Directive 96/71/EC of the European Parliament and of the Council of 16 December 1996 concerning the posting of workers in the framework of the provision of services does not to comply with the principle of subsidiarity, p. 2.

27 Parliament of the Czech Republic, Chamber of Deputies, $263^{\text {rd }}$ Resolution of the Committee on European Affairs at its 49th meeting on 31 March 2016 on the Proposal for a Directive of the European Parliament and of the Council amending Directive 96/71/EC of the European Parliament and of the Council of 16 December 1996 concerning the posting of workers in the framework of the provision of services (COM (2016) 128 final), p. 5.

28 Conclusion based on the interviews conducted in Brussels in 2017.

29 European Commission, Reply to the Reasoned Opinion adopted by the Polish Sejm, C (2016) 4827 final, Brussels, 20 July 2016, p. 2.

30 European Commission, Reply to the Reasoned Opinion issued by the Polish Senate, C (2016) 4831 final, Brussels, 20 July 2016, p. 3. 
concerns exercising an influence. The literature states that the actors may be less active when the decision is concordant with their expectations. ${ }^{31}$

In the common draft of the European Resolution (which was a part of the Information Report $\left.{ }^{32}\right)^{33}$ concerning the Proposal, the French National Assembly's Committees for European Affairs and for Social Affairs do not express their opinions on the impact of revision of the Directive on the French economy. However, the Resolution refers to the need for amending the Directive which, in their view, makes it possible to create the cheap labour market. Moreover, the Assembly welcomed the fact that the Commission changes the Directive according to the principle of equal pay for equal work. The chamber claims that posting cannot constitute a parallel job market, but it must remain a supporting mechanism for the actual exchange of goods and services on international markets. ${ }^{34}$ The Assembly also submits that the posting of workers was contrary to the principle of free and fair competition on the internal European market, and the posting of a worker who does not use the same working and wage conditions or the same social security as a local worker constituted the workaround of the subsidiarity principle of remuneration policy and social policy. Furthermore, the Assembly argued that the provisions which have been applicable so far have led to the destabilisation of individual sectors, such as the construction industry, which was used to the advantage of enterprises which chose international service providers using employees. ${ }^{35}$ In order to illustrate the scope of the aforementioned issue, the French National Assembly's Committee for European Affairs cited statistical data in the Information Report. ${ }^{36}$

31 A. Dür, Measuring Interest Group Influence in the EU. A note on Methodology, European Union Politics, Sage Publications, Vol. 9, 2008, p. 564.

32 National Assembly, Rapport d'Information déposé par la Commission des Affaires Européennes sur la proposition de directive du Parlement européen et du Conseil modifiant la directive 96/71/ CE du Parlement européen et du Conseil du 16 décembre 1996 concernant le détachement de travailleurs (COM(2016) 128 final).

33 The final version of the document adopted on 13 August 2016 could not be analysed in the paper because it was issued beyond the time frame adopted in the present paper, but it does not differ significantly from the discussed version.

34 Proposal for a European Resolution, Proposition de Résolution Européenne sur la proposition de directive du Parlement européen et du Conseil modifiant la directive 96/71/CE du Parlement européen et du Conseil du 16 décembre 1996 concernant le détachement de travailleurs (COM[2016] 128 final), Assemblée Nationale, $\mathrm{N}^{\circ} 3951$, p. 32.

35 Ibidem.

36 National Assembly, Rapport d'Information déposé par la Commission des Affaires Européennes..., p. 9. 
During the Interparliamentary Meeting, G. Savary presented, in the presence of representatives of the Commission, the impact of posting on the national social security system, the fund of which is decreasing because more and more employees are not paying contributions. The earlier, three months' membership in the social security system of the sending country and work for an employer who sends posted workers was raised by the French Senate in a political opinion sent as part of the political dialogue. ${ }^{37}$

The European Commission's replies to the French documents were brief and not very extensive in terms of the issues raised by those institutions. One should remember, however, that the arguments of that side of the debate are concordant with the arguments raised by the European Commission.

The German chambers were not so publicly active. The Bundesrat issued a resolution concerning revision of the Directive ${ }^{38}$, but it did not sent it officially to the Commission because it was a part of an exchange between the Chamber and the federal government which negotiates on behalf of Germany in Brussels. ${ }^{39}$ D. Kolat, a member of the Bundesrat, informed the participants of the Interparliamentary Meeting, including a representative of the Commission, about the above-mentioned resolution and emphasised cases of fraud, bypassing or violating the provisions by employers. She welcomed the changes concerning the application of the employment legislation of the receiving country as well as the principles of social security". ${ }^{40}$

\section{The activity of the national parliaments and the coherence of their positions}

The national parliaments could exercise an influence on the Commission thanks to the coherence of their arguments and their activity in the framework of the discussed influence channels. I will examine whether it is true that the more coherent stand of the national parliaments is, the greater influence they have on the decision

37 Senate, Commission des Affaires européennes, Avis Politique sur la proposition de révision ciblée de la directive 96/71/CE relative au détachement des travailleurs (COM (2016) 128 final), Paris, 26 May 2016, p. 2.

38 Bundesrat, Vorschlag für eine Richtlinie des Europäischen Parlaments und des Rates zur Änderung der Richtlinie 96/71/EG des Europäischen Parlaments und des Rates vom 16. Dezember 1996 über die Entsendung von Arbeitnehmern im Rahmen der Erbringung von Dienstleistungen COM(2016) 128 final, 22 April 2016.

39 Interview \#11 conducted by e-mail with an IPEX Correspondent of the Bundesrat, 24 April 2017; interview \#7 conducted by e-mail with an IPEX Correspondent of the Bundestag, 5 April 2017.

40 Transcription of the Interparliamentary Meeting organised by the French National Assembly concerning the posting of workers, 18 May 2016, pp. 13-14. 
of the Commission. In this paper, by coherence I mean the use of similar arguments in a similar way, participation in meetings concerning the discussed topic, and the frequency of actions in relation to the Commission.

The analysis of the discussed influence channels will also help judge whether a thesis that the more active the national parliaments are on the international stage, the more influential their stands are. I will examine whether Poland and the Czech Republic which issued yellow cards to oppose the revision of the Directive were active enough in the international debate to influence the decision of the Commission. I will also examine what the strategy of the countries which wanted the provisions to be changed was.

\section{Reasoned opinions and the political dialogue}

The documents adopted in the analysed period vary, depending on the side of the debate. The parliaments alleging that proposal for a revision of the Directive breaches the principle of subsidiarity issued their reasoned opinions and an opinion as part of the political dialogue, whereas the parliaments supporting the changes participated in the political dialogue to convince the Commission to implement the reform. Importantly, the Commission examines the reasoned opinions only in terms of the subsidiary principle, without considering substantive or political arguments. ${ }^{41}$

An extensive reasoned opinion issued by the Chamber of Deputies may be considered a good tool for influence, in which the said chamber attempted to present its views as well as the influence of the revision on the state's budget to the Commission $^{42}$, addressing, among others, the issue of the equal pay for equal work, providing the same justification as the Czech Senate ${ }^{43}$ and the Polish Sejm did, and the latter wrote that "the adjustment of pay rates should be the result of gradual economic development". 445

All four chambers which opposed the reform referred to the principle of subsidiarity which is the essence of the yellow card procedure and economic arguments discussed above. Three chambers raised the applying of the rules of employment specified in collective agreements to posted workers, and only the Czech Senate did not consider this in its opinion. The proposed identity of the rules of employment

\footnotetext{
41 Interview \#1 with an Official, European Commission, Brussels, 10 April 2017.

42 Parliament of the Czech Republic, Chamber of Deputies, loc. cit.

43 Senate of the Czech Republic, op. cit., p. 1.

44 Sejm of the Republic of Poland, op. cit., p. 2.

45 Own translation [translator's note].
} 
applied by temporary employment agencies to local and posted workers, and the lack of a proper justification of the revision of the Directive were raised by both Polish chambers and the Chamber of Deputies.

Of all French and German chambers in the analysed period, only the French Senate sent an opinion as part of the political dialogue. At that time, the National Assembly was preparing the European Resolution which the Commissioner was surely informed about. Both French chambers applauded the fact that the Commission had taken the initiative which, in their view, was going in the right direction.

In its opinion, the French Senate emphasised that, in its view, the Commission should propose further-reaching changes in remuneration, subcontracting and temporary employment, and that it should also limit the duration of posting to 24 months in the reference period of 36 months. Both French chambers share a similar view on the reform. In the draft European Resolution, the National Assembly also raises the issue of temporary employment, the limitation of the duration and the subcontracting chain. ${ }^{46}$

As far as the German chambers are concerned, the Bundestag did not make any written contribution to the debate, whereas the Bundesrat adopted the above-discussed resolution. From the conducted interviews, it seems that the members of the German chambers are usually very active in Brussels, however, I did not have access to any information that would confirm these statements in respect of revision of the Directive.

\section{The actions of the national parliaments}

Poland and the Czech Republic, as countries pursuing the withdrawal of the Commission's proposal, should be represented by the most active parliaments. The only direct meeting of Commissioner M. Thyssen with a parliament opposing the reform took place in April 2016 on the occasion of the scheduled meeting with the Czech Prime Minister and the Minister of Labour and Social Affairs, though no Czech chamber invited Commissioner M. Thyssen. ${ }^{47} 48$ One of the discussed topics during a joint meeting with the members of the Committee for European Affairs of both chambers of the Parliament was the revision of the Directive. ${ }^{49}$ It seems from the analysis of the activity of the Polish chambers that the Chairman

\footnotetext{
46 Proposal for the European Resolution, op. cit., p. 6.

47 Interview \#8 conducted by e-mail with an Official, Chamber of Deputies, 5 April 2017.

48 European Commission, Agenda, as of 29 April 2017, https://ec.europa.eu/commission/commissioners/2014-2019/agenda_en?field_editorial_section_multiple_tid=179.

49 Interview \#9 conducted by e-mail with an Official, Senate of the Czech Republic, 7 April 2017.
} 
of the European Union Committee of the Sejm sent a letter to the chairmen of other chambers of European parliaments in which arguments were presented to the Commission and a thorough analysis of the Commission's proposal was requested. ${ }^{50}$

As indicated above, France and Germany managed to realise their postulates concerning revision of the Directive prior to the official presentation of the Proposal, therefore, their chambers were not obligated to involve in any further actions and co-operation. In spite of that, G. Savary, who has been very committed to the making and changing of the provisions concerning the posting of workers for years, informed the members of the French National Assembly's Committee for European Affairs that after his visit to Germany, it was decided that "a contact group" concerning the posting of workers would be formed with parliamentarians from an appropriate Bundestag committee ${ }^{51}$, which was supposed to allow those chambers to reach a common position and strategy concerning revision of the Directive. Moreover, the Assembly organised an Interparliamentary Meeting which may also be considered good practice for influencing the Commission and public opinion simultaneously. The chamber also published an Information Report with the annexed draft of the European Resolution. In the framework of exchanging views with the entities interested in posting, and with the parliamentarians of the member states, Deputy G. Savary visited Poland, among others. ${ }^{52}$ What is also important, in view of his activity so far, that deputy has many contacts and extensive experience, which undoubtedly might have made it easier to influence the Commission in terms of revision of the Directive. ${ }^{53}$ When it comes to the French Senate, during the debate that took place on 26 May 2016, the members of the Committee for the European Union raised the issue of exercising an influence on the Commission and adopted the political opinion which was then delegated to the Commission as part of the political dialogue. ${ }^{54}$

The Polish chambers remained some of the most inactive chambers when it comes to attempts to influence the Commission, as they did not even organise a meeting with Commissioner M. Thyssen in Warsaw in order to present their arguments against revision of the Directive. ${ }^{55}$ From the information obtained, it

$50 \quad$ Interview \#3 with an Official, Brussels, 20 April 2017.

51 National Assembly, Rapport d'Information déposé par la Commission des Affaires Européennes..., p. 24.

52 Transcript of the session of the French National Assembly's Committee for Social Affairs, Paris, 13 July 2016, p. 27, as of 1 April 2017, http://www.assemblee-nationale.fr/14/cr-soc/15-16/c1516067.asp.

53 Interview \#5 with a Representative of the national parliament, Brussels, 24 April 2017.

54 Transcript of the session of the French Senate's Committee for European Affairs, 26 May 2016, as of 14 April 2017, http://www.senat.fr/ue/pac/EUR000002083.html\#88-4.

55 Interview \#10 conducted by e-mail with an Official, Sejm of the Republic of Poland, 14 April 2017. 
seems that a member of the Polish Senate supposedly talked to Commissioner M. Thyssen about the revision of the Directive during one of the official international meetings. ${ }^{56}$

As for the inactive German chambers, according to the information from Bundestag and Bundesrat correspondents for the interparliamentary EU information exchange platform (hereinafter referred to as IPEX): "no member of the Commission, the Cabinet or any expert from the EU institutions was invited to discuss the topic" 57 and "there has not been any official invitation or meeting between members of the Commission and the Bundesrat on this file - neither on political, nor on working level". ${ }^{58}$

\section{Interparliamentary co-operation}

Another analysed channel of influence on the Commission was participation in international meetings concerning the revision of the Directive. The representatives of the Commission were present at the meetings. The frequency of interventions and coherence between the representatives of the analysed states could influence the Commission during those meetings.

\section{The Interparliamentary Meeting}

Although the Interparliamentary Meeting was a good occasion for the national parliaments to express their views and increase the importance of their role in the European legislative process, the majority of speakers came from the parliaments which did not send yellow cards. Poland and the Czech Republic did not take advantage of this opportunity. The members of the French National Assembly and Senate and a member of the German Bundesrat spoke during the Meeting. The French speeches were more complex and addressed a wider range of arguments. The parliamentarians of both French chambers said that the protection of workers was insufficient. They also referred to the importance of the issue social security contributions, the procedure of verifying the principle of subsidiarity and chains of subcontractors, and they also welcomed the proposal concerning the equal pay for equal work. ${ }^{59}$ Only one French senator asked a question which does not seem to be concordant with the French rhetoric: "How can such a level of social protec-

\footnotetext{
56 Interview \#2 with an Official, Brussels, 10 April 2017.

57 Interview \#7.

58 Interview \#11.

59 Transcript of the Interparliamentary Meeting...
} 
tion as the one applicable in our country be imposed on countries and enterprises which cannot ensure it?". ${ }^{60}$

The only member of the German parliament who spoke was D. Kolat who referred to the challenge which for Germany means the posting of workers and she welcomed the proposal concerning revision of the Directive, which was mentioned above. The deputy added that "after 24 months, the law of the receiving country, as well as its rules of social protection, should apply"61, and she also addressed the issue of minimal pay rates and the length of posting. ${ }^{62}$

\section{COSAC conference}

The second occasion was the COSAC meeting on 11 July 2016 during which the main speaker was Commissioner M. Thyssen who referred to the control of the principle of subsidiarity in her speech, stating that the Commission took the signal sent by the yellow cards, which had been thoroughly analysed, seriously. Then she referred to "the most frequent objections submitted in the reasoned opinions". ${ }^{63}$ From the content of the speech, it seems that the decision concerning the yellow cards had already been made. The representatives of the Polish and Czech parliaments spoke during the meeting. They referred to the breach of the principle of subsidiarity expressed in the reasoned opinions issued by their chambers. Both K. Głębocki, a deputy of the Polish Sejm, and A. Maštaliř, a member of the Czech Senate referred to the arguments expressed in the reasoned opinions issued by their chambers. ${ }^{64}$ When it comes to parliamentarians coming from the countries supporting revision of the Directive, the only member who spoke was H.-J. Barchmann, a member of the Bundestag, who "underlined that it was necessary to come to a good result regarding the Directive, but that it was also important to discuss corporate social responsibility. He added that there was a need to improve the training of workers" ${ }^{\prime 6}$

\footnotetext{
60 Own translation [translator's note].

61 Own translation [translator's note].

62 Ibidem, pp. 13-14.

63 COSAC conference, Minutes of the COSAC meeting, Bratislava, 11 July 2016, pp. 7-8, as of 12 March 2017, http://www.cosac.eu/56-slovakia-2016/meeting-of-the-cosac-chairpersons-10-11-july-2016bratislava/.

64 Ibidem, p. 4.

65 Ibidem, pp. 13-14.
} 


\section{Conclusions}

Under the Treaty of Lisbon, the national parliaments were given an opportunity to submit objections to the proposed legislative acts with the principle of subsidiarity, which gives those parliaments an opportunity to participate in the Union-level politics. Unfortunately, not all chambers of the member states created mechanisms of using that principle. The purpose of this paper was to present the analysis of the actions of the parliaments of selected EU member states on the opposite sides of the dispute concerning revision of the Posting of Workers Directive and the manner of influencing the Commission by the discussed chambers in the analysed period.

In order to answer the question why the parliaments of the countries of Western Europe managed to exercise a greater influence on the European Commission's decision concerning the continuation of the work on revision of the Directive than the parliaments of Central and Eastern Europe, three variables were analysed: economic interest, the coherence of the positions presented by the parliaments and the activity of those parliaments (including their members) on the international scene.

In terms of the first variable, I assumed that the bigger economic interest of a EU member state in the posting of workers was, the more probable it would be that the arguments of the parliament of that state would be considered by the Commission. In order to prove the influence of the importance of posting, I compared the data on the number of sent and received workers, and the arguments used by the parliamentarians. It seems from the analysis that the French chambers and the German ones used arguments regarding economic interest less frequently. One may assume, however, that the Commission knows the percentage of those countries in postings, as it prepares a statistical report every year. Importantly, prior to the publication of the Proposal, France (both the government and the parliament) attempted to convince the Commission of France's stand and proposed solutions. The arguments raised by the parliaments of the Central and Eastern European states, concerning economic interests in terms of retaining the current legal framework were ignored by the Commission. The analysis presented in the paper shows that the parliaments of Western Europe managed to exercise a greater influence on the Commission because their economic interest in terms of changing the rules is more visible to the Commission.

Then I analysed arguments raised by the parliaments in official documents, and also during meetings concerning the posting of workers, in order to verify two hypotheses. As regards the statement that the more coherent stand of the national parliaments is, the greater influence they have on the decision of the Commission, 
the analysis reveals that the stand presented by the parliaments of Central and Eastern Europe was more coherent, though the arguments of the other side of the debate were similar to each other. The analysis shows that the French chambers created procedures exercising an influence on European debates and institutions, including the Commission. The German chambers did not participate in the written exchange with the Commission. Considering the above, the second hypothesis was not verified because it was not the coherence of the official stands that helped the chambers of the Western parliaments to exercise a greater influence on the Commission's decision.

Finally, I analysed the relationship between the activity of the national parliaments on the international stage and the influence exercised on the Commission. Considering the passivity of the German chambers shown in the paper, it cannot be fully claimed that it was the activity of that side of the debate that caused the Commission's decision which was positive for France and Germany. When it comes to the French chambers, they were the most active of all the analysed chambers, participating in the exchange of letters with the Commission and organising and actively participating in meetings about the posting of workers. The Polish and Czech chambers participated both in the yellow card procedure and in the COSAC conference, but no parliamentarian participated in the Interparliamentary Meeting.

Answering the question asked in the title, it should be stated that the best example of exercising an influence on the Commission are the very active French chambers, both prior to the presentation of the Commission's Proposal and within the analysed time frame. The impact on the Commission depends on sending substantive documents to the right persons, or on publicising meetings and reports presenting the supported standpoints, and also on participation in meetings during which the views of one's represented chamber can be shared.

\section{References}

Directive 96/71/EC of the European Parliament and of the Council of 16 December 1996 concerning the posting of workers in the framework of the provision of services, Official Journal of the European Communities L 18 of 21 January 1997, pp. 1-6.

Treaty on European Union, Official Journal of the European Union C 202 of 7 June 2016, p. 13-45. 


\section{Official documents}

\section{Institutions of the European Union}

European Commission, Communication from the Commission to the European Parliament, the Council and the national parliaments on the proposal for a Directive amending the Posting of Workers Directive, with regard to the principle of subsidiarity, in accordance with Protocol No 2, COM(2016) 505 final, Brussels, 20 July 2016.

European Commission, Proposal of the European Commission of 8 March 2016 for a Directive of the European Parliament and the Council amending Directive 96/71/ EC of The European Parliament and of the Council of 16 December 1996 concerning the posting of workers in the framework of the provision of services, 2016/070 (COD), Strasbourg, 8 March 2016.

European Commission, Agenda, as of 29 April 2017, https://ec.europa.eu/commission/ commissioners/2014-2019/agenda_en?field_editorial_section_multiple_tid=179.

European Commission, Country factsheet - posted workers in Poland (2015), as of 26 April 2017, ec.europa.eu/social/BlobServlet?docId=15203\&langId=en.

European Commission, Country factsheet - posted workers in the Czech Republic (2015), as of 26 April 2017, ec.europa.eu/social/BlobServlet?docId=15187\&langId=en.

European Commission, Country factsheet - posted workers in France (2015), as of 26 April 2017, http://ec.europa.eu/social/BlobServlet?docId=15194\&langId=en.

European Commission, Country factsheet - posted workers in Germany (2015), as of 26 April 2017, http://ec.europa.eu/social/BlobServlet?docId=15188\&langId=en.

European Commission, Reply to the Reasoned Opinion adopted by the Polish Sejm, C (2016) 4827 final, Brussels, 20 July 2016.

European Commission, Reply to the Reasoned Opinion issued by the Polish Senate, C (2016) 4831 final, Brussels, 20 July 2016.

European Commission, Pacolet, Josef \& Frederic De Wispelaere, Posting of workers Report on A1 portable documents issued in 2015, HIVA - KU Leuven, December 2016.

\section{Conference of the Parliamentary Committees for Union Affairs of Parliaments of the European Union}

Conference of the Parliamentary Committees for Union Affairs of Parliaments of the European Union, Minutes of the COSAC meeting, Bratislava, 11 July 2016, as of 12 March 2017, http://www.cosac.eu/56-slovakia-2016/meeting-of-the-cosac-chairpersons-10-11july-2016-bratislava/:

\section{Czech Republic}

Parliament of the Czech Republic, Chamber of Deputies, 263rd Resolution of the Committee on European Affairs at its 49th meeting on 31 March 2016 on the Proposal for a Directive of the European Parliament and of the Council amending Directive 96/71/EC of the European Parliament and of the Council of 16 December 
1996 concerning the posting of workers in the framework of the provision of services (COM (2016) 128 final).

Senate of the Czech Republic, $416^{\text {th }}$ Resolution of the Senate on the Proposal for a Directive of the European Parliament and of the Council amending Directive 96/71/EC of the European Parliament and of the Council of 16 December 1996 concerning the posting of workers in the framework of the provision of services, COM (2016) 128, 27 April 2016.

\section{France}

Transcript of the Interparliamentary Meeting organised by the French National Assembly concerning the posting of workers, 18 May 2016.

Transcript of the session of the French National Assembly's Committee for Social Affairs, Paris, 13 July 2016, as of 1 April 2017, http://www.assemblee-nationale.fr/14/ cr-soc/15-16/c1516067.asp.

Transcript of the session of the French Senate's Committee for European Union, 26 May 2016, as of 14 April 2017, http://www.senat.fr/ue/pac/EUR000002083.html\#88-4.

Draft European Resolution, Proposition de Résolution Européenne sur la proposition de directive du Parlement européen et du Conseil modifiant la directive 96/71/CE du Parlement européen et du Conseil du 16 décembre 1996 concernant le détachement de travailleurs (COM[2016] 128 final), Assemblée Nationale, $\mathrm{N}^{\circ} 3951$.

National Assembly, Rapport d'Information déposé par la Commission des Affaires Européennes sur la proposition de directive du Parlement européen et du Conseil modifiant la directive 96/71/CE du Parlement européen et du Conseil du 16 décembre 1996 concernant le détachement de travailleurs (COM(2016) 128 final.

National Assembly, Rapport d'information de la commission des Affaires européennes déposé par la commission des affaires européennes sur le bilan d'activité de la commission des Affaires européennes (XIVè législature, 2012-2017), 4 avril 2017, $\mathrm{N}^{\circ} 4605$.

Senate, Commission des Affaires européennes, Avis Politique sur la proposition de révision ciblée de la directive 96/71/CE relative au détachement des travailleurs (COM (2016) 128 final), Paris, 26 May 2016.

\section{Germany}

Bundesrat, Vorschlag für eine Richtlinie des Europäischen Parlaments und des Rates zur Änderung der Richtlinie 96/71/EG des Europäischen Parlaments und des Rates vom 16. Dezember 1996 über die Entsendung von Arbeitnehmern im Rahmen der Er-bringung von Dienstleistungen $\operatorname{COM}(2016) 128$ final (Decision concerning the proposal for a Directive of the European Parliament an of the Council amending Directive 96/71/EC of the European Parliament and of the Council of 16 December 1996 concerning the posting of workers in the framework of the provision of services (COM(2016) 128 final), 22 April 2016. 


\section{Poland}

Senate of the Republic of Poland, Opinia Komisji Spraw Zagranicznych i Unii Europejskiej Senatu Rzeczypospolitej dotycząca projektu Dyrektywy Parlamentu Europejskiego i Rady zmieniająca dyrektywę 96/71/WE Parlamentu Europejskiego i Rady z dnia 16 grudnia 1996 r. dotyczącą delegowania pracowników w ramach świadczenia usług COM (2016) 128 przyjęta na posiedzeniu w dniu 12 kwietnia 2016.

Sejm of the Republic of Poland, Reasoned opinion of the Polish Sejm of 13 April 2016 stating reasons why the Sejm considers that the proposal for a directive of the European Parliament and of the Council amending Directive 96/71/EC of the European Parliament and of the Council of 16 December 1996 concerning the posting of workers in the framework of the provision of services does not to comply with the principle of subsidiarity.

Narodowy Bank Polski (NBP), Kursy średnioważone walut obcych w złotych (Tabela A), http://www.nbp.pl/home.aspx?f=/kursy/arch_a.html.

Główny Urząd Statystyczny (GUS), Przeciętne miesięczne wynagrodzenie w gospodarce narodowej w latach 1950-2017, stan na 23 września 2018 roku, https:/stat.gov.pl/ obszary-tematyczne/rynek-pracy/pracujacy-zatrudnieni-wynagrodzenia-koszty-pracy/przecietne-miesieczne-wynagrodzenie-w-gospodarce-narodowej-wlatach-1950-2017,2,1.html.

\section{Derivative sources}

Bokhorst D., Schout A., Wiersma J.M., The Emperor's New Clothes? A Political Evaluation of the Early Warning Mechanism, "The International Spectator" 2015, Vol. 50, No. 2.

Dür A., Measuring Interest Group Influence in the EU. A note on Methodology, European Union Politics, SAGE Publications, Vol. 9, 2008.

Eurofound, Statutory minimum wages in 2015: Pay - Q4 2014 (EurWORK topical update), Eurofound, 2017.

Jancic D., The game of cards: National Parliaments in the EU and the future of the Early Warning Mechanism and the political dialogue, "Common Market Law Review" 2015, Vol. 52.

\section{Original sources}

\section{Interviews in person}

Official, European Commission, Interview \#1, Brussels, 10 April 2017.

Official, Interview \#2, Brussels, 10 April 2017.

Official, Interview \#3, Brussels, 20 April 2017.

Official, DG Employment, European Commission, Interview \#4, Brussels, 24 April 2017. Representative of the national parliament, Interview \#5, Brussels, 24 April 2017.

\section{By e-mail}

IPEX correspondent, Bundestag, Interview \#7, 5 April 2017.

Official, Chamber of Deputies of the Czech Republic, Interview \#8, 5 April 2017. 
Official, Senate of the Czech Republic, Interview \#9, 7 April 2017. Official, Sejm of the Republic of Poland, Interview \#10, 14 April 2017. IPEX correspondent, Bundesrat, Interview \#11, 24 April 2017. 